\title{
The Smile Aesthetics of Pentecostal Thought in the Age of covid
}

This issue is like a smile set on a beautiful new face as it features the hope that emerges with the flashes of brilliance from a new generation of scholars of Pentecostalism. The first of the smiling curves is carved by an essay on what a theologically astute pastoral response to pandemics should look like. It informs pentecostal pastors on how to respond adequately to the covid crisis ravaging the world. The second curve that contours the facial typography is about prayers, especially prayers that Pentecostals offer to God for the healing of their loved ones afflicted by the virus. How can they be sure that God answers their specific prayers for healing? The second essay provides a philosophically grounded response to this question.

In between the two smiling curves are white sharpened teeth that cut into philosophy to inform, educate, and reframe pentecostal epistemology and notions of sacramentality. The usefulness of the four essays in this group goes beyond clarifying concepts to embracing practical advice on how to live the pentecostal life, to participate in the life of God, and to practice missionally for the healing of creation. Indeed, these essays, rooted in analytical and continental branches of philosophy, can contribute meaningfully to the spiritual lifeto its epistemological, relational, missiological, and evangelical dimensionsof Pentecostals.

The six essays in this volume are arranged in the smiling-curve format so that readers' response to this edition will sweep upward at each end of the collection. The world is suffering under the deadly hammer of the coviD-19 pandemic and Pentecostals need to craft adequate theological, pastoral, and institutional responses to it. The opening and closing essays in this edition will help in this regard. The arrangement of the six essays is tailored to focus attention on the covid crisis that has engulfed the world. However, symbolically, the placement of the smiling-curve essays is a testament of our collective hope that, while weeping may endure for a night, joy will come in the morning. Between the night and the morning - as if the Holy Saturday between the Good Friday of crucifixion and Easter Sunday of resurrection-we need the wisdom of philosophy as a way of life to guide us into proper belief, right praxis, and right emotion. Philosophy here witnesses to the beauty, profundity, and 
complexity of life in the Spirit and to the ever-unfolding character of Pentecostal theology. The four essays that are between the covid-focused ones offer hopes of renewal of praxis, thought, and affection in the global pentecostal movement. Their placement in the in-between symbolically creates a space for pentecostal scholars, pastors, and lay people to learn to remain in the space of reimagination and deliberation instead of succumbing to the common ethos of triumphantly skipping over to the victory over or the end of the pandemic that is sure to come. The in-between space, like the gap of Holy Saturday, calls Christians to witness to the work of the Holy Spirit in the in-between spaces of communal vulnerability, isolation, and separation that today traverse the fabric of social existence.

The first of the six essays, written by Geoffrey Butler, retrieves ideas and reworks Christian tradition to offer practical advice on how pastors should respond to the CoviD-19 crisis on the basis of faith and sound theology. Using Martin Luther's writings on suffering and pandemic, especially the bubonic plague that troubled Wittenberg in 1527 , Butler constructs a theological ballast to correct "the long-held imbalance in pentecostal theology" of suffering and response to plagues. The end result is a succinct discursive and practical theological framework for pastoral response to pandemics.

Melissa Davis's essay on ecclesiological renewal takes us directly into the "teeth" of philosophy in this edition of Pneuma. She argues that the church is an ontological reality (meaning it has an ontological identity) with epistemological praxis to tradition its members for participation in the life of Christ, to "learn to be according to the rhythm of the kingdom of God." The ontological identity flows from the recognition that the church was created (chosen) before the foundation of the creation of the universe and that those called and incorporated in it are called into an entity that is undergirded and empowered by the Holy Spirit. The traditioning is the set of practices, liturgies that point believers to and draw them into sacramental participation in the life of Godand in this way it renews the church.

Monte Lee Rice's essay is also on sacramentality but taken from a different angle. He recasts the typical pentecostal eschatological expectation as "sacramentally tuned practiced eschatology." He translates the eschatological expectation into bodily acts that enact and materialize the eschaton, the coming kingdom of God. Drawing from God's promise to pour out God's Spirit on all flesh, Rice offers a theo-philosophical reinterpretation of sacramentality that takes flesh and materiality of human existence seriously. This move, he argues, is to enable Pentecostals to embrace more fully the potentials of their embodied practices in ways that counter hostility toward alterity and accent the hospitality of God's kingdom. Put differently, he reimagines the usual pentecostal 
eschatological urgency as missionally practicing for social justice, world transformation, and the healing of creation.

The essay that follows Rice's is philosophical not in the usual sense but in the sense of philosophy as a way of life. This coauthored essay shows how the prosperity gospel has become an invitation to Charismatics and Pentecostals to transform themselves into businessmen and -women directly hooked to the jouissance of the neoliberal market. If in the past the prosperity gospel was a magical spork to extract choice meat from the bubbling neoliberal caldron of soup, it is now offered as a way of life that unabashedly sets up Pentecostals and Charismatics to participate directly in the gigantic apparatus of global profit extraction. Jayeel Cornelio and Erron Medina's essay thus opens up a new dimension of the prosperity gospel in the Philippines: the transformation of prosperity preachers into financial coaches. There is a shift from the principles of "seed faith" and "faith confession" that magically promise abundance to practices geared toward directly extracting "profits" and "returns" from the neoliberal capitalist market. The prosperity gospel in this nation, as the authors demonstrate, is a now a technology that is both religious and entrepreneurialat least, in the hands of Bo Sanchez and Chinkee Tan. Analyzing the recent incarnation of the prosperity gospel in the Philippines, Cornelio and Medina show how these two leaders train their followers to save, invest, and start entrepreneurial business ventures even as they point them to biblical verses for securing prosperity. They offer sociological explanation of why this shift has occurred in the Philippines. The expansion of the middle class in the country has thrown up millions of Christians into the religious market or the churches who "appreciate the logic and discipline of financial management."

The next essay is philosophical in the usual sense. It reframes pentecostal postmodern epistemology as theorized by James K.A. Smith into "externalist epistemology." Yoon Shin argues that Smith's theory of epistemologynamed narrative, affective knowledge-is informed or grounded in foundational, properly basic beliefs of Pentecostalism, and as such it is not burdened by narrative arbitrariness, story relativism, and infinite regress, as some of his critics maintain. The key point Shin argues is that the truth claims of Pentecostals embedded in their testimonies, stories, and narratives arise from a belief-dependent process.

From externalist epistemology the reader is taken to the epistemology of and theology of prayers. This is the second of the smiling curves that parenthesize Covid-19 and transform its despair into hope. It asks the question: How can a Christian know that God has answered her petitionary prayer? If she prayed for an event and it happens, how could she be justified in saying God answered her prayer apart from direct revelation from God? Christopher 
Woznicki holds that even when believers do not have access to direct revelation about answered prayers, they can still hold the belief that God answered their prayers. Based on the application of the principle of credulity to the notion of spiritual senses/spiritual perception, he states that spiritual conception could be considered as credible if there is no sufficient reason to reject it. If the perception is warranted, then the believer's belief in the success of her prayer is also warranted. And her case is made even stronger if Christian teachings on prayers provide for belief that God answers prayers, which they certainly do.

Amidst this difficult epoch in which a global pandemic has thrown agendas off and conspiracy theories have taken root as another plague in popular Christianity, a fresh face of scholarship here brings an aesthetic beauty in the deep ontological forays of our contributors. We hope that our readers will be buoyed by this face that points forward to the future of pentecostal scholarship.

Nimi Wariboko and L. William Oliverio, Jr. 